\title{
UČINKI SLOVENSKEGA GEOGRAFSKEGA PROSTORA NA ORGANIZACIJO ZRAČNE OBRAMBE
}

\author{
Jože Konda*
}

Izvleček:

UDK: 355.3/.4:911.3(497.4)

Zračna obramba postaja v sodobnem bojevanju vse pomembnejša sestavina. V Slovenski vojski je zračna obramba rod, ki se tesno vključuje predvsem v bojno delovanje letalstva in t.i. težkih rodov (artilerija in oklep). Temeljne naloge zračne obrambe so pravočasno opozarjanje pred napadi iz zračnega prostora, organizirano delovanje sil za preprečevanje napadov in izvajanje ukrepov za usklajeno delovanje in bojevanje s cilji v zračnem prostoru. Prvenstvena naloga je obramba ključnih objektov državne in gospodarske infrastrukture in najpomembnejših enot Slovenske vojske.

Organizacija in izvajanje zračne obrambe je tesno povezano z geografskim prostorom. Geografski prostor vpliva tako na izbor najugodnejših lokacij za izvajanje nadzora in bojevanja v zračnem prostoru ter na dostop do takih lokacij. Praksa kaže, da je slovenski geografski prostor zelo zahteven za organizacijo in izvajanje zračne obrambe.

Ključne besede: Zračna obramba, nadzor zračnega prostora, radarski in ognjeni položaji, komunikacije.

\section{THE EFFECT OF THE SLOVENIAN GEOGRAPHIC SPACE ON THE ORGANISATION OF AN AIR DEFENCE}

\begin{abstract}
:
An air defence is becoming more and more important part of modern warfare. In the Slovenian armed forces it is a branch which closely cooperates with an air force and with so called heavy branches (artillery and armor). The basic tasks of an air defence are warning against an air attack and conducting of fight against an enemy aircraft. It is responsible for both protection of a high value sites and protection of the main defence forces. Organisation and performing of an air defence is tightly connected with a geographycal environment.Geography influences on arranging of radar sites, deployment of an air defence units, approach to good location, supply etc. Experiances in such an activities are heavy proofed.
\end{abstract}

Key words: Air defence, air surveillance, radar and missile sites, communication

* Brigadir: Verifikacijski center Slovenske vojske, Ministrstro za obrambo. 


\section{UVOD}

Republika Slovenija (v nadaljevanju Slovenija) je majhna evropska država, ki je še posebej ranljiva iz zračnega prostora. $\mathrm{Z}$ zračno nevarnostjo se je srečala že $v$ samem začetku bojnih delovanj v I. svetovni vojni. Tudi v osamosvojitveni vojni leta 1991 ji je iz zraka grozila največja nevarnost.

Slovenski geografski prostor je zelo razčlenjen. Povprečna nadmorska višina je $460 \mathrm{~m}$. Pogozdenost je krepko nad polovico. Pretežni del lokacij uporabnih za organizacijo zračne obrambe je težje dostopen zaradi številnih naravnih in umetnih ovir. Problemi se pojavljajo pri uporabi lokacij za organiziranje in izvajanje nadzora zračnega prostora in pri organiziranju in izvajanju učinkovite zemeljske zračne obrambe. Veliko število dolin in podo$\mathrm{lij}^{1}$ (še posebej v smeri severozahod - jugovzhod, oziroma jugovzhod - severozahod), ki vodijo od meja proti osrednji Sloveniji, omogoča relativno prikrit let zračnih plovil v notranjost Slovenije. Zelo malo je ugodnih višinskih lokacij, ki bi omogočale namestitev radarskih naprav za opazovanje zračnega prostora čim dlje izven Slovenije.

\section{ZGODOVINSKE IZKUŠNJE}

Slovenski zračni prostor je bil vključen v bojna delovanja v pretekle spopade od prve svetovne vojne dalje. V I. svetovni vojni so Italijani bombardirali aŠJK IĆvstrijsko zaledje, t.j. slovensko ozemlje vključno z Ljubljano. V. II. svetovni vojni so bombardirali slovensko ozemlje tako okupatorji (Novo mesto, Dragatuš) kot tudi zavezniki (Žužemberk, Borovnica, Litija). Iz časa po II. svetovni vojni so znana številna kršenja slovenskega (takrat še jugoslovanskega) zračnega prostora (znan je primer sestrelitve ameriškega bombnika leta 1946 nad severno Primorsko, pa tudi prebeg sovjetskega pilota iz Madžarske v Italijo v začetku osemdesetih). V vojni za samostojnost je Slovenijo napadlo vojaško letalstvo Jugoslovanske ljudske armade (JLA), ki je nadaljevala z grožnjami tudi po umiku iz Slovenije. Zračni prostor samostojne Slovenije je bil v začetku devetdesetih let predmet nenehnih kršitev s strani Hrvaške. bilo pa je tudi večje število kršitev iz Italije in nekaj iz Avstrije. Zanimiva je tudi najnovejša uporaba slovenskega zračnega prostora $v$ podporo akciji Skupnih sil na območju Zvezne republike Jugoslavije (ZRJ). To kaže na pomen njegove umestitve $v$ evropskem prostoru. Pri tem ni odveč spomniti na odmetavanje infra rdečih (IR) vab zavezniških letal nad območjem Trbovelj.

Slovenija se umeščena na območju prehoda iz Padske v Panonsko nižino Južnoevropskega bojevališča. Čez to območje so prehajale Rimske legije proti vzhodu in barbarska plemena proti zahodu. $V$ začetku našega štetja leta 395 , je na tem območju potekala pomembna bitka za ohranitev Rimskega cesarstva. Tudi II. svetovna vojna se je zaključila na območju Slovenije. Množica Čez slovensko ozemlje potekajo številne operativne smeri. Temeljna zahteva sodobnega bojevanja je osvojitev in vzdrževanje prevlade $\mathrm{v}$ zračnem prostoru. Z obvladanjem zračnega prostora dobi napadalec proste roke pri bojnem delovanju na zemlji. Zaradi majhnosti moramo čim bolje izrabiti pozitivne lastnosti slovenskega geografskega prostora. To pomeni učinkovito izrabo ugodnih terenskih lokacij za organi-

I Savska dolina, Vipavska dolina, Pivško podolje, Notranjsko podolje, Ribniško-kočevska dolina, Dolenjsko podolje. Celjska kotlina z. Rogaškim podoljem, Mislinjska dolina 
ziranje sistema zračne obrambe, predvsem zaradi zračne obrambe pomembnih objektov in učinkovite zaščite obrambnih sil v Sloveniji.

Pri usposabljanju enot zračne obrambe Slovenske vojske je bilo izvedenih kar nekaj raziskav slovenskega geografskega prostora za potrebe nadzora zračnega prostora in za uporabo ognjenih enot zračne obrambe (predvsem lahkih prenosnih raketnih sistemov). Nekdanja JLA ni izvajala temeljitejše raziskave v ta namen. Obstajal je le en dokument 9. A (armade) iz konca osemdesetih let, ki je navajal nekaj lokacij, ki bi lahko bile uporabne za potrebe zračne obrambe. Dokument je bil na vpogledu v odseku za zračno obrambo (oZO) leta 1992, vendar se je nekje izgubil. Ni znano ali obstaja kakšen podoben dokument $v$ arhivih nekdanjega poveljstva nekdanjega Jugoslovanskega vojnega letalstva in zračne obrambe (JVLZO). Ob koncu sedemdesetih in v začetku osemdesetih let je bilo nekaj aktivnosti tedanjega 350. raketnem polku protizračne obrambe (rp PZO) v določanju možnih lokacij² za uporabo enot ZO (Vrh Trebnje, Topla reber pri Dvoru) in tedanjega 91. bataljona za zračno opazovanje, javljanje in usmerjanje (bVOJIN) (Modrasovec). V vojni za Slovenijo je bila nekaj časa v uporabi (radar 3MK7) lokacija na Obolnem (776 m n. v.) severno od Višnje gore, po vzpostavitvi suverenosti slovenskega zračnega prostora (08.10.1999) pa na Lisci (948 m n. v.) obalni akvizicijski radar (OAR-61).

Tematika je bila delno obdelana tudi v Konceptu zračne obrambe leta 1993, ki je služil kot podlaga za kasnejšo izdelavo Študije izvedljivosti sistema VLZO. Delno je bila tematika obdelana tudi v študiji Natove analitične celice zračne obrambe (NATO Analitical Air Defence Cell - NAADC) in Nizozemske firme FEL/TNO. Geografski prostor Slovenije je bil delno obdelan tudi v študiji »Electronic System Center United States Air Force (ESC USAF) - Regionalna zračna iniciativa in firme Lockheed Martin - variante radarskega pokrivanja Slovenije in okolice ${ }^{3}$. Tematika zračne obrambe je zajeta tudi $v$ Elaboratu Generalštaba Slovenske vojske (GŠ SV) za izvajanje šolskih bojnih streljanj enot zračne obrambe s topovskimi in lahkimi raketnimi orožji na osrednjem vadišču Postojna.

\section{SEDANJI RAZLOGI}

Namen teme je predstaviti slovenski geografski prostor v vsej raznolikosti in njegov učinek na organizacijo zračne obrambe Slovenije oziroma Slovenske vojske. ${ }^{4} \mathrm{~V}$ temo so vključene nekatere dosedanje aktivnosti na področju preučevanja in ocenjevanja slovenskega geografskega prostora za potrebe zračne obrambe.

Predstavljene so zmogljivosti in omejitve geografskega prostora Slovenije pri organizaciji in izvajanju učinkovitega sistema zračne obrambe. Dejanska uporaba večine lokacij, ki bi zagotovile čimbolj učinkovito izrabo zmogljivosti sredstev za nadzor zračnega prostora in izvajanje bojevanja s cilji v zračnem prostoru, je omejena. Nekatere lokacije, ki jih je upo-

2 Poleg že obstoječih za raketne enote: Kosmă̌ pri Postojni, Medvedje brdo, Pasja ravan, Valburga. Jančce. Gradišnica pri Grosupljem. Brege pri Krškem in nadzor zră̌nega prostora Ljubljanski vrh, Oljska gora/Soteški hrib, Vrhloga in delno Modrasovec.

3 Vse študije (Izvedljivosti, NAADC, Nizozemska, ESC in LM) se nahajajo v oZO GS̆SV.

4 Za ponazoritev zahtevnosti načrtovanja in izvajanja zračne obrambe v Sloveniji naj navedem primer; ko smo zaprosili za pomoč tuje ekspertne organizacije. NAADC (NATO Analitical Air Defence Cell) in skupino za načrtovanje v poveljstvu vojaškega letalstva Kraljevine Nizozemske. Obe sta obljubili hitro rešitev: Ko pa sta se srečali z zahtevnostjo slovenskega reliefa, sta priznali, da problem presega čas, ki ga imata na razpolago. Zato smo dobili le delne rešitre. 
rabljala JLA (radarski položaji Ljubljanski vrh, Soteški hrib/Oljska gora, Modrasovec, Vrhloga, Pohorje/Ledinekov Kogel in raketni položaji Pasja ravan, Medvedje brdo, Kosmač, Postojna/Ostri vrh, Logatec/Sleme, Gradišnica, Janče, Valburga, Gorice in Brege) so razen Ljubljanskega vrha in Soteškega hriba (Oljske gore) le delno uporabne. Mirnodobni čas ni naklonjen pripravi in uporabi lokacij za potrebe zračne obrambe. Še posebej ne zato, ker senzorji, na katerih temelji nadzor zračnega prostora in delovanje zračne obrambe, uporabljajo za svoje delovanje pretežno elektromagnetno energijo. Slednja vzbuja, sicer največkrat neupravičeno, odpor javnosti.

Predmet obravnave je zemeljska sestavina zračne obrambe ${ }^{5}$ (obsega nadzor zračnega prostora in obdelavo podatkov o stanju v njem ter uporabo orožij za bojevanje s cilji). Opisane so tudi možne lokacije za uporabo sredstev in orožij zračne obrambe in zahteve, ki jih morajo lokacije izpolnjevati. Zračna obramba mora razpolagati z ustreznimi pogoji za delovanje. V slovenskem primeru je zemljišče ključnega pomena.

$\mathrm{Z}$ opisom značilnosti, posebnosti in omejitev slovenskega geografskega prostora, je podana osnova za organizacijo in izvajanje nadzora zračnega prostora v Sloveniji in izven nje ter izvajanje bojevanja s cilji v zračnem prostoru in možnosti za zaščito pred napadi iz le tega.

Uporabljeni so tudi izsledki empiričnih raziskav $\mathrm{v}$ katerih je avtor sodeloval ali so bile izvedene na podlagi načrtov uporabe enot. Izvedenih je bilo več vaj enot za nadzor zračnega prostora in enot zračne obrambe, ki so določene ugotovitve potrdile, za določene pa pridobile dejanske podatke ${ }^{6}$, ki so včasih odstopali od pričakovanih. ${ }^{7}$

Kot potrditev določenih trditev so uporabljeni strokovni izsledki ustrezno podprtih strokovnih organov, npr.: program »Nika 1.0 Službe za informatiko MORS avtorja inž. Marjana Slaka ${ }^{8}$; računalniška obdelava kombinacij radarskega pokrivanja Slovenije firme Lockheed Martin $^{9}$ z uporabo »Extended Air Defense Simulation in Level 0 Digital Terrain Elevation Data«; in vrednotenje možnih radarskih lokacij, ki so jo izvedli pripadniki 16. bataljona za nadzor zračnega prostora (bNZP) ${ }^{10}$.

\section{ZNAČILNOSTI GEOGRAFSKEGA PROSTORA SLOVENIJE}

Slovenski geografski prostor je bil predmet obdelave znanih slovenskih geografov ${ }^{11}$. Kljub temu je potrebno poudariti nekatere vidike, ki so pomembni za organizacijo in izvajanje zračne obrambe, relativno mlade dejavnosti ${ }^{12}$, ki uspešnost svojega delovanja v veliki meri

5 Težišče je na zač̌ni obrambi prostora in pomembnih objektov v njem. Zračna obramba enot je dosti bolj prilagodljiva.

6 V času kalibracije radarja "Giraffe" ne Mirni gori je helikopter lebdel nad vasjo Milici v Beli krajini, na levem bregu reke Kolpe, radar pa je kazal njegovo lokacijo 2 km znotraj hrvaškega zračnega prostora.

7 Organiziran pristop k preučevanju geografskega prostora Slovenije za uporabo enot zračne obrambe z. lahkimi prenosnimi raketnimi sistemi je bil pričet v oktobru 1991. Izvajali so ga v takratnih PŠTO in 9. rbr ZO. Gradiva so v 9. rbr ZO in arhivih PŠTO. Kasneje so raziskave izvajali v 9. rbr ZO v okviru izvajanja raznih vaj in aktivnosti na področju ZO. Ob koncu 1992 je bil izveden helikopterski oblet večine možnih lokacij za izvajanje nadzora zračnega prostora in enot ZO. Lokacije so bile posnetes TV kamero iz. COU Poljče.

8 Pri 16. bNZP in pri stotniku dr: Pavlu Popoviču.

9 Radar Coverage of the Republic of Slovenia, Lockheed Martin Tactical Defense Systems, Eagan. MN, USA, 1998 (voZO GŚSV - podpolkovnik Zvonko Lah).

10 Del raziskav je bil narejen leta 1995, celovitejši del pa 1998. Gradiva-RAPOL 98 so v 16. bNZP (stotnik Stanislav Lokajner in stotnik dr: Pavle Popovič).

II Gams, Klemenčič, Kunaver; Melik in drugi. Z vojaško obrambnega vidika ga je zelo dobro opisal v doktorski disertaciji Zvonimir Bratun (Bratun, Z., 1998: Geografski dejavniki državnovarnostnega sistema Republike Slovenije, doktorska disertacija, Ljubljana.).

12 Zračna obramba je po Zakonu o obrambi, 1995, rod Slovenske vojske. 
gradi na učinkoviti izrabi prostora. Slovenci večkrat mislimo, da dobro poznamo našo deželo, ki naj bi bila lahko prehodna, vendar temu ni tako. Na tako majhnem geografskem prostoru kot je Slovenija, je v Evropi kar težko najti toliko raznolikosti. Zato je potrebno vedno znova poudarjati pomen geografskega prostora za vojaško obrambne potrebe. To velja tako za vse pripadnike Slovenske vojske, še posebej pa to velja za pripadnike zračne obrambe $v$ aktivnem (nadzor zračnega prostora in bojevanje s cilji v njem) in pasivnem (zaščita pred napadi iz zračnega prostora in odpravljanje posledic napadov) delovanju.

\subsection{Geografski položaj ${ }^{13}$}

Slovenija, s površino $20.256 \mathrm{~km}^{2}$, leži na prehodu iz Padske v Panonsko nižino in na stičišču jugovzhodnega obrobja Alp z Dinarskim gorstvom. Po največji diagonali (od Pirana do Hodoša) doseže okoli 260 km, povprečna širina pa je okoli 100 km v zahodnem in osrednjem in okoli $40 \mathrm{~km} v$ vzhodnem delu.

$\mathrm{S}$ štiridesetimi kilometri morske obale in pristaniščem Koper je tudi mediteranska država, kar ji povečuje prometni pomen. Zaradi poteka petega evropskega koridorja preko nje ima tudi pomemben geostrateški položaj v Evropi.

Osrednji predeli Slovenije skupaj z glavnim mestom Ljubljano so oddaljeni od meja le nekaj minut poleta sodobnega vojaškega letala. Razdalje od meja do Ljubljane ${ }^{14}$ so (v ravni liniji): okoli $45 \mathrm{~km}$ od Ljubelja, okoli $82 \mathrm{~km}$ od Rateč, okoli $68 \mathrm{~km}$ od Vrtojbe, okoli 64 km od Sežane, okoli $64 \mathrm{~km}$ od Staroda, okoli $80 \mathrm{~km}$ od Metlike in okoli $94 \mathrm{~km}$ od Obrežja. Gospodarsko zelo pomemben energetski kompleks Šoštanj je od Rogatca oddaljen okoli 53 $\mathrm{km}$, od Obrežja okoli $75 \mathrm{~km}$ in od Holmca okoli $27 \mathrm{~km}$. Maribor je praktično dosegljiv z zemeljske površine tako z juga kot tudi s severa.

Poleg navedenih kratkih razdalj od meja, ki jih sodobno letalo, s spodnjo bojno hitrostjo $900 \mathrm{~km} / \mathrm{h}$ $(15 \mathrm{~km} / \mathrm{min})$, preleti v nekaj minutah, predstavlja zračni obrambi veliko težavo pravočasno odkrivanje nasprotnikovih plovil na skrajnem dosegu senzorjev ${ }^{15}$. V Sloveniji je le malo ugodnih lokacij za namestitev radarjev dolgega dosega. Najugodnejšo lokacijo na Menini planini (1426 m n. v.) je zaradi nasprotovanja okoljevarstvenikov nemogoče uporabiti ${ }^{16}$. Od tu bi bil koristen radarski nadzor zračnega prostora podaljšan daleč proti vzhodu, jugovzhodu, jugu in zahodu. To bi omogočilo več časa za odziv sistema ZO in večjo učinkovitost orožij ZO. Kako pomembna je višina namestitve radarja pove podatek, da radar na Ljubljanskem vrhu (819 m n. v.) zaradi zakrivljenosti zemeljske površine zazna cilj na skrajnem dosegu če je višini okoli $11.000 \mathrm{~m}$ nad morsko površino. $\mathrm{Z}$ dvigom na $1426 \mathrm{~m}$ n. v. bi se višina zaznavanja znižala na $3300\left(\right.$ !) $\mathrm{m}^{17}$.

Slovenija ima tudi zelo pestro podnebje, od submediteranskega v Primorju do celinskega v Prekmurju. Padavine niso enakomerno porazdeljene, v goratem predelu Julijskih Alp (Bovec) pade blizu $4000 \mathrm{~mm}^{18}$, naprej proti vzhodu pa se ta količina postopno zniža na okoli $800 \mathrm{~mm}$. Tudi Primorje je precej siromašno s padavinami kar se izraža predvsem v težavi z vodooskrbo. Prehod med letnimi časi ni več tako izrazit. Kljub temu je v jesen-

13 Povzemam po: Gams, I., 1996: Geograftske značilnosti Slovenije, Mladinska knjiga, Ljubljana.

14 Na tozadevno zračno nevarnost so opozarjali že avtorji Zgodovine slovenskih mest, 1939

15 Teoretično lahko sodobni radar AN/TPS-70 odkrije cilj v zračnem prostoru odsevne površine $5 \mathrm{~m}^{2}$ na razdalji od 240 do 444 km, kar pomeni v prečniku od Muenchna do reke Drine.

16 Potrebno bi bilo zgraditi vsaj petsto metrov poti.

$17 D o=\sqrt{2} R z(\sqrt{ } H a+\sqrt{ } H c)$ :

Do - daljava odkrivanja radarja, Rz - radij Zemlje, Ha - višina antene, $H c$ - višina cilja. 
skem, zimskem in zgodnje spomladanskem času pričakovati znatne vremenske spremembe, ki lahko bistveno vplivajo na organizacijo in izvajanje zračne obrambe. Zahtevni vremenski pogoji pa tudi omejujejo možnost napadov iz zračnega prostora.

\subsection{Orografske značilnosti}

Površina Slovenije je zelo razgibana, s povprečno višino okoli $460 \mathrm{~m}$ nad morsko gladino. Razen primorskega pasu, se rečne ravnice nikjer ne spustijo pod $100 \mathrm{~m}$ nadmorske višine. Kljub temu, da več kot polovica Slovenije ne presega višine $500 \mathrm{~m}$ nad morjem, predstavlja geografska razčlenjenost velik izziv za organizacijo zračne obrambe. Kljub majhnosti je slovenski geografski prostor razčlenjen. Za našo obravnavo zadošča splošna regionalna členitev na Alpe, Dinarsko gorstvo, Subpanonsko in Submediteransko Slovenijo.

Nadzor zračnega prostora se izvaja v kombinaciji več radarskih sredstev v osnovni in rezervni radarski mreži in v kombinaciji s senzorji v enotah zračne obrambe, ki so razmeščeni na večjem območju. Tudi ognjene enote zračne obrambe izvajajo zračno obrambo v različnih ravneh in $v$ različnih okoljih, kar pomeni, da je potrebno upoštevati specifičnosti posameznih regij $\mathrm{v}$ Sloveniji. Orografske značilnosti Slovenije bistveno učinkujejo na načrtovanje in izvajanje integrirane zračne obrambe. Razgiban relief omejuje uporabo sredstev zvez, s tem pa tudi informacijsko podporo na kateri temelji integrirana zračna obramba. V primeru izpada kateregakoli člena je zaradi premajhne izdatnosti lahko ogroženo delovanje sistema.

\subsection{Prometna infrastruktura}

Slovenija ima dobro razvito prometno infrastrukturo. Ogrodje predstavlja prometni križ s sečiščem v Ljubljanski kotlini. Glavne prometnice potekajo od severa proti jugu in od zahoda proti vzhodu. Cestnega omrežja je okoli $14.000 \mathrm{~km}$ in železniškega okoli $297 \mathrm{~km}$. Pretežni del prometa se odvija okoli večjih mestnih središč, vendar je tudi večina regionalnih in lokalnih cest dobro prevoznih. Na glavnih cestnih in železniških prometnicah je veliko objektov (mostov, viaduktov, usekov, nasipov, predorov), ki predstavljajo potencialni cilj napadov iz zračnega prostora. ${ }^{19}$ Največ takih objektov je na relaciji Maribor - Koper: Pragersko, Celje, Zidani most, Litija, ranžirna in železniška postaja v Ljubljani, Ravbarkomanda, Prestranek, Divača. Občutljivost ostalih objektov prometne infrastrukture niha odvisno od trenutne situacije.

Slovenska letališča omogočajo učinkovito povezavo Slovenije s svetom. Osrednjega pomena je Letališče Brnik. Zato so leta 1991 tedanje zvezne letalske oblasti Letališče Brnik najprej zaprle za ves promet, ga nato napadle iz zraka in poiskušale dodatno zasesti na tleh. Vojaško letališče Cerklje ima neugodno lego zaradi bližine meje z Republiko Hrvaško. Letališči Maribor in Portorož imata manj pomembno vlogo, vendar predstavljata pomembna elementa letalske infrastrukture. To so tudi manjša letališča v Novem mestu, Velenju in Slovenj Gradcu in športna letališča v Sloveniji.

Pomorski promet je zgoščen v Kopru, kar mu daje z narodno-gospodarskega vidika izreden pomen, kot tudi prometne povezave $\mathrm{v}$ notranjost države. Zato predstavlja posebej občutljiv element prometne infrastrukture, ki zahteva posebno pozornost pri načrtovanju in organizaciji zračne obrambe.

Poseben pomen imajo številne gozdne ceste. Omogočajo dostop do ugodnih višinskih lokacij, kjer je možna uporaba sil zračne obrambe. Kljub temu so višje ležeče lokacije, na gora-

$18 V$ zadnjih letih ta količina bistveno niha, vendar je potrebno upoštevati slabšo možnost.

$19 V$ času letalskih napadov zveze NATO na ZRJ so bile prometnice med najpomembnejšimi cilji. 
tih/hribovitih območjih Dolenjske, Notranjske, Primorske, zahodne Štajerske in Julijskih Alp običajno težko dostopne tudi v poletnem času, še slabše pa je pozimi.

Gozdnatost Slovenije in relativno visoka poseljenost onemogočajo uporabo ustreznih lokacij za izvajanje zračne obrambe ${ }^{20}$. Veliko število mostov, nadvozov/podvozov postavlja pred načrtovalce zahtevno nalogo predhodnega iskanja in določanja prometnih smeri za organizacijo in izvajanje zračne obrambe $v$ neposredni vojni nevarnosti pa tudi za zavarovanje le teh.

\subsection{Poseljenost in industrija}

Slovenija je relativno gosto poseljena. Zagotavljanje potreb prebivalstva izpostavlja veliko število objektov, ki so občutljivi za napade iz zračnega prostora. To so elementi družbene infrastrukture (informacije, komunikacije, energetika, promet) in objekti političnega in gospodarskega pomena. Posebej so izpostavljeni objekti obrambne infrastrukture. Njihova obramba zahteva vključitev močnih sil zračne obrambe v prvi fazi za alarmiranje in v drugi za bojevanje proti napadalcem iz zračnega prostora. Pomemben dejavnik je tudi odpravljanje posledic napadov iz zračnega prostora, kar dodatno vpliva na organizacijo zračne obrambe. Posebej je izpostavljen problem učinkovite obrambe jedrske elektrarne Krško (JEK).

Tabela: Pregled najbolj občutljivih objektov na napade iz zračnega prostora:

\begin{tabular}{|c|c|c|}
\hline Področje ogroženosti & Objekt & Lokacija \\
\hline Obramba & $\begin{array}{l}\text { Poveljstva, letališča, } \\
\text { vojašnice, skladišča }\end{array}$ & \\
\hline Gospodarstvo & $\begin{array}{l}\text { Farmacevtska, avtomobilska, } \\
\text { predelovalna, lahka in težka } \\
\text { industrija }\end{array}$ & $\begin{array}{l}\text { Krka, Revoz, Belinka, reaktor } \\
\text { Podgorica, Lek, Color, Smodnišnica } \\
\text { Kamnik, Sava Kranj, Železarne } \\
\text { Ravne in Jesenice in drugi. }\end{array}$ \\
\hline Energetika & $\begin{array}{l}\text { Nuklearna elektrarna } \\
\text { Termoelektrarne } \\
\text { Hidroelektrarne } \\
\text { Razdelilne postaje } \\
\text { Visokonapetostni daljnovodi }\end{array}$ & $\begin{array}{l}\text { Krško } \\
\text { Šoštanj, Ljubljana, Trbovlje, } \\
\text { Brestanica } \\
\text { Na Dravi, Savi in Soči } \\
\text { Kleče/Ljubljana, Divača, }\end{array}$ \\
\hline Politika & $\begin{array}{l}\text { Vlada, Predsednik RS, } \\
\text { Parlament }\end{array}$ & Ljubljana, Maribor \\
\hline Komunikacije & Komunikacijska vozlišča & Krim, Boč, Nanos, \\
\hline Informacije & TV oddajniki & $\begin{array}{l}\text { Krvavec, Nanos, Krim, Kum, } \\
\text { Trdinov vrh, Plešivec, Pohorje }\end{array}$ \\
\hline Promet & $\begin{array}{l}\text { Železniška in cestna križišča, } \\
\text { tuneli, nadvozi, mostovi, } \\
\text { letališča }\end{array}$ & $\begin{array}{l}\text { Zidani most, Lj. Moste, } \\
\text { Ravbarkomanda, predor Karavanke } \\
\text { Letališča Brnik, Maribor in Portorož }\end{array}$ \\
\hline $\begin{array}{l}\text { Kultura in kulturna } \\
\text { dediščina }\end{array}$ & $\begin{array}{l}\text { Zgodovinski spomeniki in } \\
\text { objekti }\end{array}$ & $\begin{array}{l}\text { Ljubljanski grad, Postojnska jama, } \\
\text { stara mestna središča, ccrkve }\end{array}$ \\
\hline
\end{tabular}

20 Običajno so na lažje dostopnih vrhovih pomembni kulturnozgodovinski objekti (cerkve, gradovi,...) 
Načrtovanje in izvajanje zračne obrambe $v$ bližini naselij in pomembnih gospodarskih objektov mora upoštevati tudi možne posledice, ki bi jih povzročilo delovanje enot zračne obrambe na cilje v zračnem prostoru. Cilj mora biti uničen preden prileti v območje objekta ali velikega mesta. $Z$ bojnim delovanjem nanj $v$ območju mesta ali branjenega objekta, bi bile posledice lahko celo večje.

\section{VOJAŠKO GEOGRAFSKE SMERI NA OBMOČJU REPUBLIKE SLOVENIJE}

Eden izmed najpomembnejših dejavnikov geografskega prostora so vojaško geografske smeri. Njihov pomen ostaja skozi zgodovino. Menja se le način in obseg njihove uporabe. 21

Bratun $(1997,161)$ vsestransko in podrobno obravnava tematiko vojaško geografskih smeri na območju Slovenije. Običajno se vojaško geografske smeri pokrivajo tudi z možnim delovanjem letalstva, zato ima njihovo poznavanje velik pomen za preučevanje uporabe zračne obrambe in to:

- zaradi ustreznega organiziranja sil in sredstev zračne obrambe,

- zaradi potrebe po koordinaciji delovanja sil zračne obrambe in letalstva $\mathrm{v}$ podpori silam na zemlji

- zaradi čim boljše usklajenosti uporabe sil zračne obrambe in bojnega delovanja enot

- zaradi načrtovanja ustrezne informacijske in komunikacijske podpore in tudi

- zaradi načrtovanja ustrezne izdatnosti.

Z vidika prostorske organiziranosti zračne obrambe so predmet obravnave pretežno operativne smeri. Uporaba oziroma poznavanje zemljišča s taktičnega oziroma vidika lastne obrambe je manj zahtevno, vendar še vedno izredno pomembno. ${ }^{22}$ Taktični nivo se podrobneje obravnava v pripravi in izvajanju taktičnih vaj in načrtuje za vsako situacijo posebej. Letalstvo se pri svoji uporabi, tudi v Sloveniji, srečuje z vso zahtevnostjo, ki jo določa zračni prostor. Na videz neomejen in zahvaljujoč sodobnim tehnologijam zelo pregleden, je za uporabo še vedno zelo zahteven. Spremenljivost zračne situacije povezana z vremenskimi spremembami in zahtevnim reliefom na zemlji, še vedno predstavlja napadalcem iz zračnega prostora znatno oviro. Tudi zato poskušajo za letenje uporabljati čim manj nevarne poti. Običajno so operativne smeri dobro »pokrite« z zračno obrambo in njihove zmogljivosti za uporabo letalstva so omejene. Razmaknjen bojni razpored, potreben prostor za manever in prostor, ki ga »zasedajo« letala za razne zagotovitve ${ }^{23}$, omejuje številčnost letal v napadih na cilje na tako majhnem prostoru kot je Slovenija. To pomeni, da je na operativni smeri moč pričakovati omejeno (čeprav še vedno relativno veliko) število letal. Izračun tega števila mora temeljiti na dobrih obveščevalnih informacijah in dobrem poznavanju območja bojevanja (kateri in koliko ciljev je za nasprotnika »donosnih«, kakšna je vremenska situacija, kaj nasprotnik ve o naši zračni obrambi, itd.)

21 Čez. slovenski prostor so v preteklosti prodirala ljudstva od zahoda proti vzhodu (Rimski imperij, Italijani,...), od vzhoda proti zahodu (Slovani, Avari, Huni,...), od severa proti jugu (Goti, Franki,Nemci,...) in od juga proti severu (Turki, pa tudi JLA.

22 Pomembno je poznati zmogljivosti sektorja, smer in položaj sonca, vidljivost, meglenost, dostopnost, oskrbo, zavarovanje, maskiranje, ...

23 Izku.šnje iz. 78-dnevnih napadov Zaveznikov na ZRJ leta 1999 kažejo, da je bilo, čeprav v docela drugačnih okoliščinah, takih letal več kot polovica. 
Poznavanje vojaških geografskih smeri je izredno pomembno za organiziranje zračne obrambe tako zaradi zgoraj navedenih razlogov, še bolj pa zaradi predhodnega ( $\mathrm{v}$ miru) preučevanja in priprave možnih lokacij. Geografski prostor se ne menja tako hitro kot vojna situacija, zato pomeni njegovo dobro poznavanje bistveno prednost za organizatorje zračne obrambe, tako aktivne kot tudi pasivne. Vendar pa je treba vedeti tudi to, da operativna vojaško geografska smer na zemljišču ni identična tisti v zračnem prostoru.

Zahtevnost delovanja zračne obrambe se bistveno poveča z uporabo lastnega letalstva. Brez izredno učinkovitega sistema razpoznavanja lasten-tuj je uporaba lastnega letalstva tvegana. ${ }^{24}$ Določanje »koridorjev« je z vidika razvoja bojne situacije večkrat vprašljivo, vendar se $z$ dobrim poznavanjem geografskih dejavnikov nevarnost za lastna plovila bistveno zmanjša.

Poznavanje vojaških geografskih smeri je izredno pomembno za organiziranje zračne obrambe zaradi predhodnega ( $v$ miru) preučevanja in priprave možnih lokacij. Geografski prostor se ne menja tako hitro kot vojna situacija, zato pomeni njegovo dobro poznavanje bistveno prednost za organizatorje zračne obrambe, tako aktivne kot tudi pasivne.

Dobro poznavanje smeri omogoča učinkovito organizacijo mreže opazovalnih postaj in organizacijo ovir (hitro dvigajoči se baloni do $1500 \mathrm{~m}$ višine).

\subsection{Zahodna smer}

Zahodno smer sestavljata Primorska ${ }^{25}$ in Gorenjska smer. Zmogljivost Primorske smeri je ena eskadrilja (squadron) ${ }^{26} \mathrm{v}$ enem naletu. ${ }^{27}$ Osnovni problem pri organizaciji zračne obrambe so omejene možnosti za opazovanje zračnega prostora. Zaradi ogroženosti ni možno uporabljati lokacij bliže meji ${ }^{28}$, lokacije globlje v notranjosti pa ne omogočajo nadzor zračnega prostora izpod $1000 \mathrm{~m}$ n. v. Nekdanje JVLZO je imelo organiziran/sklenjen pas zračne obrambe Ljubljane proti zahodu: Valburga, Pasja ravan, Medvedje brdo in Kosmač. ${ }^{29}$

Zmogljivost Gorenjske smeri je manjša, do enega letalskega oddelka/krila. Ozko kanalizirana smer olajšuje organizacijo zračne obrambe (opazovanje po globini) v primeru leta na majhnih višinah.

$\mathrm{V}$ primeru leta na velikih višinah ${ }^{30}$ je zračna obramba omejena na opozarjanje pred zračno nevarnostjo.

\subsection{Severna smer}

Zaradi gorske verige Karavank in Pohorja je ta smer za organizacijo zračne obrambe najzahtevnejša. Ne omogoča nadzor zračnega prostora, zaradi majhne globine pa tudi zelo skrajšuje potreben reakcijski čas zračne obrambe. Racionalno je načrtovati zračno obrambo na taktični ravni.

24 Izkušnje iz Zalivske vojne 1991 kažejo, da so Zavezniki sestrelili nekaj svojih plovil, kljub dobro razvitemu sistemu identifikacije lasten-tuj. Da niti ne omenjamo izraelsko-arabske junijske vojne!

25 Os smeri je Tržič - Ljubljana, v vsako smer se razteza v širino okoli $20 \mathrm{~km}$.

26 Okoli 18 do 20 letal.

27 Preverjanja vizvajanju skupnih vaj nekdanjih 350. rp PZO in 117.lap. Posebni izračuni za določitev dejanskega števila letal še niso bili narejeni.

28 Nekdanje VLZO je imelo do Osimskih sporazumov radarsko opazovalno postajo v Lokvici na Krasu.

29 Z raketnim sistemom S-125M. doseg raket $25 \mathrm{~km}$, in 12 lastnih radarjev dosega 250, 180 in $70 \mathrm{~km}$.

30 Dokler ne bo imela zracna obramba Slovenske vojske oborožitve ustreznega dosega. 


\subsection{Južne in jugovzhodne smeri}

Slovenija je najbolj odprta proti jugu in jugovzhodu (»mehki trebuh«). Zmogljivosti teh smeri so velike (brigadne velikosti). V zračnem prostoru omogočajo nalet sil velikosti najmanj polka/winga. Izkušnje iz osamosvojitvene vojne kažejo, da so plovila takratnega JVL kljub relativni odprtosti reliefa, uporabljala »kanalizirane « prehode (Jelšane, Babno polje, Stari trg, Črmošnjice, Vahta/Gorjanci, Brežice, Rogatec, Ormož).

Z ustrezno organizacijo radarske mreže je možno zagotoviti dokaj dobro pokritost zračnega prostora na višinah nad $1000 \mathrm{~m} \mathrm{n}$. v., višinah $100 \mathrm{~m} \mathrm{n}$. v. pa so še vedno luknje, ki pa jih je moč zapolniti z opazovanjem.

\section{* Notranjska smer}

Os Notranjske smeri se začenja pri Reki, nadaljuje proti Postojni in naprej proti Ljubljani. Smer določa kanaliziran vstop, vendar se kasneje pri Postojni razcepi. Smer je zelo zahtevna za organizacijo nadzora zračnega prostora zaradi Snežnika in Javornikov. Zmogljivost eskadrilje v koloni.

\section{* Dolenjska smer}

Os smeri leži v smeri Karlovac - Ljubljana. Pretekle izkušnje kažejo, da je možno organizirati dobro radarsko opazovanje zračnega prostora z obronkov Mirne gore in Smuka nad Semičem. Zmogljivost do eskadrilje.

\section{* Posavska smer}

Leži na osi Zagreb - Ljubljana. Ta smer je najbolj zmogljiva, vendar omogoča zelo dobro organizacijo sil in sredstev zračne obrambe po širini in globini. Izkušnje $z$ vaj enot 9 . rbr $\mathrm{ZO}$ samostojno in skupaj $\mathrm{z}$ enoto zračne obrambe nizozemskega kraljevega letalstva. ${ }^{31}$ Zmogljivost eskadrilje.

\section{* Podravska smer}

Leži na osi Varaždin - Maribor. Smer je zelo odprta. Omogoča dostop do Maribora in po notranji smeri do Ljubljane. Ugodna je za organizacijo in izvajanje zračne obrambe. Zmogljivost eskadrilje.

\section{POGOJI ZA UPORABNOST ZEMLJIŠČA ZA ORGANIZACIJO ZRAČNE OBRAMBE}

\subsection{Preglednost zračnega prostora}

Temeljna potreba zračne obrambe je popoln pregled nad zračnim prostorom. Zračni prostor v katerem deluje zračna obramba, predstavlja celoten zračni prostor $v$ dosegu senzorjev s katerimi le ta razpolaga. Pri tem so senzorji bojnih enot zračne obrambe tudi v funkciji senzorjev za nadzor zračnega prostora. Senzorji izvajajo opazovanje zračnega prostora in zagotavljajo podatke za ocenjevanje situacije v njem. V ustreznem operativnem centru izdelujejo pregledno sliko stanja $\mathrm{v}$ zračnem prostoru in tako zagotavljajo potrebne 
podatke za delovanje sistema zračne obrambe, ki alarmira, izvaja zračno obrambo in kontrolira nosilce in izvajalce. Integriran sistem zračne obrambe zajema usklajeno angažiranje in delovanje celotne zračne obrambe. Enote in orožja zračne obrambe morajo imeti na razpolago čimveč razpoložljivega časa za pravočasen izračun potrebnih elementov in odpiranje ognja na napadalce iz zračnega prostora.

Na podlagi že izvedenih raziskav prostora in navedenih študij, je bilo temeljiteje obdelanih 20 možnih lokacij za razmestitev senzorjev za nadzor zračnega prostora. Le manjši del lokacij zagotavlja ustrezno pokrivanje majhnih višin.

Pri izboru lokacij za radarske položaje je bilo upoštevanih več kriterijev:

- možnost normalnega opazovanja zračnega prostora v krogu $360^{\circ}$

- možnost formiranja sevalnega diagrama glede na razgibanost zemljišča in tip radarja

- postavitev infrastrukture $\mathrm{z}$ vso potrebno elektronsko opremo ${ }^{32}$

- zagotovitev minimalnih električnih industrijskih motenj

- minimalni vpliv radarja na okolico

- možnost dostopa do položaja

- nadaljnje izgradnje objektov v okolici

- zaščita od naravnih nesreč (snežni plazovi, požar in podobno)

Lokacije pa morajo omogočati tudi:

- obrambo pred napadi iz zračnega prostora in z zemlje

- uporabo slepilnih sredstev

- redno oskrbo

- obvladljive vremenske pogoje

- hiter izmik, itd.

\subsection{Dostop na ustrezne položaje}

Tesno povezana s preglednostjo je višina namestitve senzorjev. Običajno so najvišji vrhovi, s katerih bi bilo možno opazovati zračni prostor v skrajnem dosegu senzorjev, težko dostopni oziroma nedostopni zaradi strme konfiguracije terena ali zaradi zelo zahtevnih klimatskih pogojev za njihovo delovanje.

Lokacije, ki jih načrtujemo za uporabo, morajo biti dostopne, najbolje po zemlji. Poti, ki vodijo do njih morajo biti dovolj zmogljive za prevoz tovorov ustreznih dimenzij in teže. Morajo biti grajene tako, da jih je moč vzdrževati tudi v zahtevnih meteoroloških pogojih, predvsem pozimi. Zelo pomembna je tudi pretočnost komunikacij za zagotovitev hitrega premika na novo lokacijo. Če je senzor blokiran na poti, pomeni to ișto kot da je izločen iz uporabe, iz boja.

Zaradi okolje varstvenih nasprotovanj je izbira ustrezne lokacije za izvajanje nadzora zračnega prostora odvisna ne samo od same dostopnosti, pač pa tudi od pripravljenosti družbe za razumevanje obrambnih potreb.

Problem dostopnosti se nanaša tudi na lokacije primerne za delovanje ognjenih enot zračne obrambe. Visoko ležeče lokacije v okolici branjenih objektov so običajno zasedene (stavbe ali drevesa). Zaradi večje izdatnosti je zelo pomembna čimbolj zmogljiva prometne infrastruktura, ki omogoča hiter manever na področju izvajanja bojnega delovanja.

32 Pasja ravan (s protne višine $1029 \mathrm{~m} \mathrm{n}$. v., je bila ob koncu 70)-ih let "znižana" za okoli $15 \mathrm{~m}$, da bi bila uporabljena za ognjeni rakemi položaj. pa še takrat so bila postavljena le 3 od 4 raketna izstrelišsca). 


\subsection{Možnost logistične zagotovitve in samoobramba}

Oskrba in logistična zagotovitev enot na lokacijah s katerih izvajajo naloge, predstavlja velik izziv za načrtovalce. Predvsem za enote, ki izvajajo nadzor zračnega prostora velja, da se lahko najdejo $\mathrm{v}$ pogojih daljše fizične odrezanosti od sveta. V postojankah JLA na Krimu in Ljubljanskem vrhu (v neposredni bližini Ljubljane!) je prihajalo do občasnih težav pri oskrbi in zagotovitvi tehničnih pogojev za delovanje zaradi snežnih zametov. ${ }^{33}$

Sredstva, orožja in enote zračne obrambe morajo biti ustrezno branjene pred napadi iz zračnega prostora in z zemlje. Zemljišče mora zagotoviti ustrezno razmestitev enote zračne obrambe zaradi povečanja učinkovitosti njenega delovanja in tudi zaradi njene večje zaščite. Zaradi vse večje uporabe »stand-off« orožij, daje slovenski geografski prostor omejene možnosti za organizacijo izpostavljenih obrambnih položajev zračne obrambe t.j. uničenje platforme preden odvrže/izstreli izstrelek.

Posebej je izpostavljen problem pasivne obrambe pred napadi iz zračnega prostora (motilniki in slepilna sredstva), kar mora biti postavljeno $\mathrm{v}$ ustrezni bližini ${ }^{34}$ radarskega sredstva.

\section{ZAKLJUČKI}

\section{Majhnost prostora}

Slovenski geografski prostor je majhen in se razteza od zahoda proti vzhodu. Poleg tega, da je razvlečen, ga stanjšujejo še globoke zajede (Razkrižje, Rogatec, Babno polje). Tako je povprečna širina, okoli $100 \mathrm{~km}$ v zahodnem in osrednjem in okoli $40 \mathrm{~km} \mathrm{v}$ vzhodnem delu), še bolj relativna. Praktično je slovenski zračni prostor možno preleteti preden katerikoli v svetu znani sistem zračne obrambe v miru posreduje. Tudi po dolžini (okoli 225 km) ga lahko sodobno letalo preleti v manj kot desetih minutah. Še pomembneje je, da so najpomembnejši objekti razporejeni v osrednjem delu, kar prepolovi potreben čas doleta, če pa vzamemo v ozir še stand-off orožja (doseg 10 do $40 \mathrm{~km}$ in več), potem praktično ne moremo govoriti o globini. Zaradi taktičnih razlogov je v ožjem obmejnem pasu primerna uporaba manj učinkovitih sredstev in orožij zračne obrambe (prenosni radarji in rakete majhnega dosega).

\section{Velika razgibanost reliefa}

Severni in severozahodni del predstavlja praktično nepremostljivo oviro za učinkovit nadzor zračnega prostora. Visoka gorovja Alp predstavljajo velik zaklonski kot za izvajanje nadzora z zemlje. Šele območje Predalpskega hribovja daje možnost uporabe lokacij za namestitev senzorjev, ki pa so bolj učinkoviti v nadzorovanju zračnega prostora proti vzhodu in jugu, deloma tudi proti zahodu.

\section{Pomanjkanje ustreznih lokacij}

Zaradi velike razgibanosti in strukture reliefa, je število ugodnih lokacij za namestitev senzorjev za nadzor zračnega prostora relativno majhno. Z metodo izbora po karti je bil že leta

33 Znan je primer iz nekdanje JLA, ko se je na radarskem položaju Plješivica (Bihać) zaradi izredno surovih vremenskih pogojev, smrtno ponesrečil vojak, ki je izvajal oskrbo.

34 Najmanjšso razdaljo določa varnost pred izstrelki, ki bi padli na motilnik, največjo pa izračun verjetnosti. da se bo izstrelek, ki se je »zaklenil« na radar preusmeril na motilnik. 
1992 izveden helikopterski oblet in snemanje že znanih in možnih lokacij. V kasnejših letih pa so $\mathrm{v} 9$. raketni brigadi $\mathrm{ZO}$ in $\mathrm{v} 16$. bNZP izvedli terenski ogled po vnaprej določenem načrtu in določenih kriterijih in ugotovili dejansko stanje.

\section{Zahtevni klimatski pogoji}

Tako temperatura kot tudi padavine dosegajo v posameznih obdobjih ekstremne vrednosti (hud mraz do -30 (C, obilne padavine več sto litrov v teku dneva). Padavine v zimskem času bistveno ovirajo promet, še posebej pa omejijo dostopnost do višinskih lokacij. Tudi megla $v$ spomladanskem in jesenskem času pokriva večji del kotlin in dolin. Večji del višinskih lokacij ima zelo zahtevne klimatske pogoje, ki otežujejo uporabo le teh, še posebej pa normalno delovanje v ekstremnih pogojih (veter, sneg, dež, mraz, strele).

Najustreznejše lokacije na katerih načrtujemo namestitev radarskih in oborožitvenih sistemov zračne obrambe, so običajno težko dostopne. Poleg same namestitve opreme in orožij zračne obrambe, morajo te lokacije zagotoviti tudi pogoje za bivanje članov posadk in $v$ končni fazi tudi zagotovitev samoobrambe. Bivanje $v$ zimskih pogojih zahteva še dodatne zagotovitve, ne le prehrano in toplo streho. Še posebej v vojni situaciji so pogosta stresna stanja, ki zahtevajo vzdrževanje ustreznih komunikacij s člani posadk.

\section{Prometna (ne)dostopnost}

Slovenija ima dobro razvito prometno infrastrukturo za normalen potek prometa. Vendar strm relief, razčlenjen $\mathrm{v}$ doline in kotline, otežuje dostopnost do lokacij, ki so ugodne za uporabo za potrebe zračne obrambe. Dostop do najvišjih lokacij je težak, v zimskem času pa večinoma nemogoč ${ }^{35}$.

\section{PREDNOSTI IN SLABOSTI SLOVENSKEGA GEOGRAFSKEGA PROSTORA}

\subsection{Prednosti}

Majhnost geografskega prostora je lahko tudi prednost, saj mora eventualni napadalec $v$ zelo kratkem času in hitro odkriti načrtovani cilj napada. Ob vedenju, da je v času izvajanja bojne naloge ves čas $v$ nevarni coni ognjenega delovanja enot zračne obrambe, je možnost učinkovitega delovanja še manjša.

Tudi nepredvidljiv relief in neugodni vremenski pogoji so prednost za organizacijo zračne obrambe saj zahtevajo od morebitnega napadalca let na večjih višinah, kjer pa je bolje viden.

Razmeroma dobro razvite komunikacije omogočajo hiter premik sredstev in orožij zračne obrambe.

Razgiban relief omogoča aktivno uporabo raznih slepilnih sredstev in vab, kar lahko zmede napadalca. Doline, pa tudi razni prehodi (sedla), je moč »posejati« z raznimi pasivnimi sredstvi (baloni na 1000 - $2000 \mathrm{~m}$ dolgih sidrih, ki se lahko hitro sprožijo ali pa »potegnejo«), ki so za vsakega pilota izredna psihološka in tudi fizična ovira.

35 Vsaka posamezna lokacija ima več »obrazov«. To potrjujejo tudi osebne izkušnje z izvajanja vaj nekdanjega 350. rp PZO. Primer: dostop do Medvedjega brda je poleti le kratek izlet. Tudi v zimi z nizkim snegom je dostopnost obvladljiva. V primeru visokega snega pa je dostop nemogoč. Tudi ustrezna zimska oprema (verige - »kramponi «) je v takih primerih brez. moči. Podobno velja npr: tudi za Pasjo ravan. Poleg snega obstaja še nevarnost zemeljskih plazon; ki lahko blokirajo enoto. 


\subsection{Slabosti}

Zaradi velikega števila »mask « je potrebno zagotoviti bistveno večje število senzorjev in večjo raznovrstnost orožij zračne obrambe za delovanje v različnih pogojih.

Zagotavljanje komunikacij za upravljanje s sistemom zračne obrambe je bistveno zahtevnejše. Povezava vseh senzorjev v enoten sistem nadzora zračnega prostora zahteva izredno zmogljivo informacijsko opremo.

Majhnost geografskega prostora omogoča večjo uporabo stand-off orožij.

Težko je zagotoviti varen let lastnemu letalstvu kadar je bojna situacija hitro spremenljiva.

\section{SKLEP}

Slovenski geografski prostor je majhen. Razdalje od meja v notranjost so za sodobna sredstva za napad iz zračnega prostora kratke in hitro premagljive.

Zelo razgiban relief omejuje število lokacij primernih za razmestitev enot za zračno obrambo, še posebej za nadzor zračnega prostora. Ugodne lokacije so ali težko dostopne ali »zasedene« $\mathrm{z}$ objekti.

Zmogljivosti orožij in sredstev zračne obrambe pogojujejo ustreznost lokacij za njihovo namestitev.

Organizacija telekomunikacijskih in informacijskih povezav v zračni obrambi zahteva, zaradi razgibanega reliefa, angažiranje večjega števila sredstev, kot bi to bilo potrebno glede na fizične razdalje.

Razgibanost geografskega prostora omogoča izvajanje ukrepov zaščite pred napadi iz zračnega prostora in razmestitev različnih pasivnih sredstev zračne obrambe.

\section{Literatura in viri:}

- Bratun, Z.,1997: Geografski dejavniki državno varnostnega sistema Republike Slovenije, Doktorska disertacija, Filozofska fakulteta, Oddelek za geografijo, Ljubljana.

- Gams, I., 1996: Geografske značilnosti Slovenije, Založba Mladinska knjiga, Ljubljana

- Zgodovina slovenskih mest, Skupina avtorjev, 1939, Ljubljana

- Študija NAADC, Bruselj, 1998

- Študija FEL/TNO, Nizozemska, 1998

- RAPOL 98 (raziskave 16. bNZP radarski položaji 1998)

- Raziskave in zapiski avtorja in pripadnikov zračne obrambe Slovenske vojske v času od 1. 1991 naprej; delovne beležnice avtorja in elaborati vaj v 9. rbr ZO

- Lockheed Martin, 1999: Študija - Variante radarskega pokrivanja slovenskega zračnega prostora

\section{SUMMARY}

Slovenia is a small country. It is positioned in a very trafficable region between Italian Po plane and mostly Hungarian Pannonia plane. Its size is small and distances between borders are short. That means that the sensitive points in central region are easy approachable and threatened by an enemy's attack. The terrain is not friendly for organization of proper air defence. The highest points which are proper for organization of effective air defence net are settled by artificial or natural objects i.e. air defence obstacles.

The Slovenian geography is very rich. It consists of all the sorts of geogaphycal phenomenons. Mountains, hills, planes, rivers create very changable situation which is sometimes 
good and sometimes bad for organization of air defence even for attackers. The terrain is the most influential element in the organization and establishment of an effective air defence. Climat has a strong influence in deployment of air defence assets in almost half of a year. Snow, cold and rain could prevent deployment on the one hand and prevent air attacs on the other.

In Slovenia there are a lot of very sensitive points, which have to be protected from the aerial attacs. This fact demands engagement of a lot of sensors and proper layered air defence assets. On the other hand the terrain offers a good protection for troops.

Slovenia's geographical facts have to be fully considered when the air defence is designing.

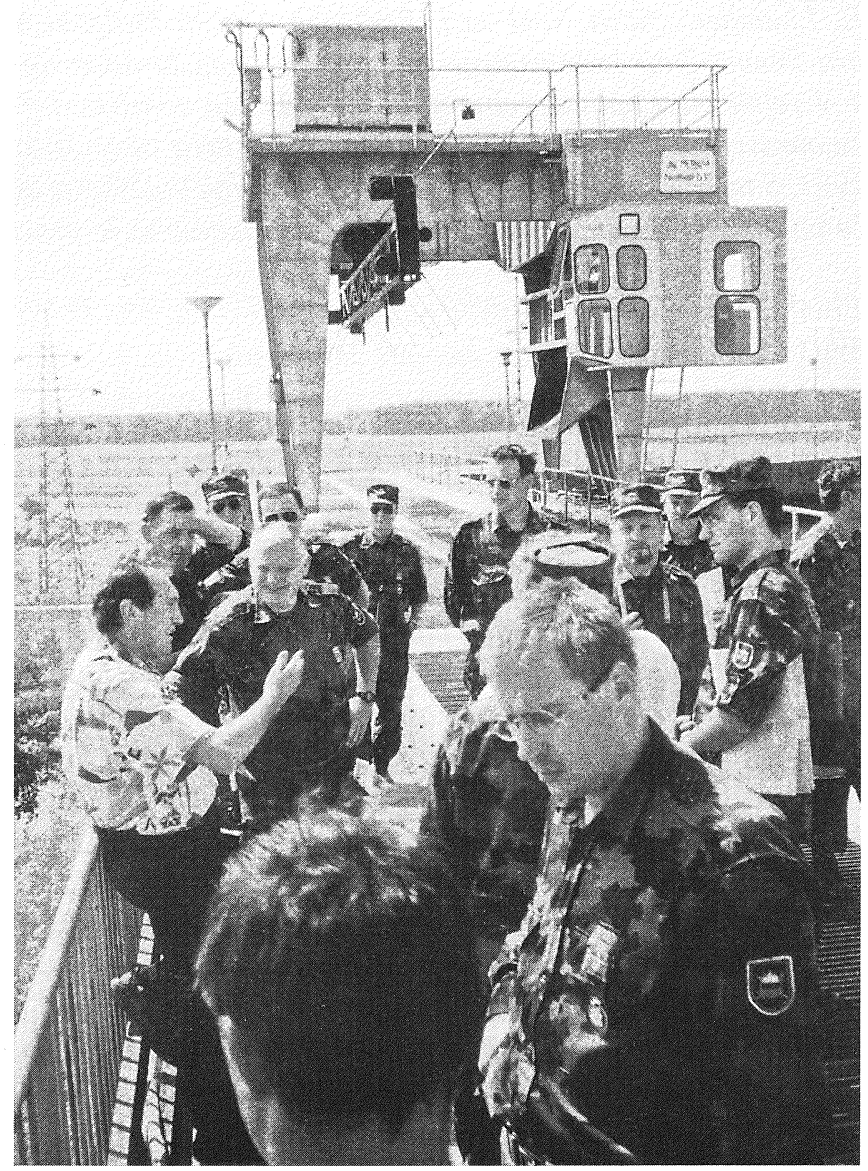

Slika: Slušatelji Poveljniško štabne šole na pregardi Zlatoličje, kanal Zlatoličje maj 1998. Foto: Nataša Rot 